\title{
The Cultural Significance in Greeting Practices in Belo Dialect of the Bima Language
}

\author{
Alek \\ UIN Syarif Hidayatullah, Jakarta-Indonesia \\ alek@uinjkt.ac.id \\ DOI: https://doi.org/10.18326/rgt.v12i2.175-195
}

\begin{abstract}
Submission
Track:

ABSTRACT

Received:

$13-08-2019$

Greeting personal name in local languages are unique and various from

Final Revision: one to another language, island, and cultural group. One of these is Bima language, especially in Belo dialect. The recent study expects to

21-11-2019 reveal the three main issues as follows (1) How many patterns of greeting name variations using in Belo dialect of the Bima language?

Available online: (2) How are the variations pattern constructed in the greeting of $01-12-2019$ personal names in Belo dialect of Bima language? (3) What are the most

Corresponding often vocal sound patterns used in greeting the personal names in Belo dialect of Bima language? The research used a qualitative descriptive study. The collection used some procedures, namely interviews,

Author:

Name \& E-mail Address recording, documentation. The data analyzed with a qualitative descriptive that followed Miles and Hubermann. The results show that there are four patterns variation in greeting personal male names and eight variations in greeting female names; the second, there are three

Alek alek@uinjkt.ac.id ways of constructing the patterns of greeting names, namely at the beginning, the middle, and the end of the syllables; and the most often syllable vocal pairs used /e-o/for male names and syllables / $a-u /$ and le-o/vowel pairs for female names. It is crucial to scrutinize the local languages and their cultures contained within. This implication of recent study results expects to evoke the speakers of regional languages have a responsible and sense of belonging to their language and culture.
\end{abstract}

Keywords: Greeting practices, Bima language, and cultural significance 


\section{INTRODUCTION}

Greeting of the personal name becomes a crucial aspect of daily human interaction. Each language has unique ways or patterns in the greeting of personal names. Bima language (BL) used in Bima regency, and it has some dialects within; one of them is the Belo dialect (BD). It used in all aspects of the Bimanese life from family, daily, culture, religion, rituals, education, and event in the traditional interactions. Regarding the greeting of personal names in the local languages, a scholar states that "Every language has at least two relation systems, the term of greeting or addressing and term of reference" (Koentjoroningrat, 1980 in Hamidsyukrie, et al., 1994, p. 3). There are some researchers have done the investigation related to greeting names, among them are (Yannuar, 2017; Felecan, 2015; Pennesi, 2017; and Croft, 2017).

Furthermore, Kridalaksana (1984, p. 171) states that terms of greeting are morpheme or phrases that are widely used to chat with each other on certain interaction circumstances and may be different based on the kind of relationships between the communicators. To a similar extent, language or speech plays a significant role in stabilizing the social structure. It also means, the social status also have their unique variation of expression that is widely used to survive their existence (Alwasilah, 1985, p. 102).

Term of greeting in most of the Indonesian tribes divided into at least three significant categories viewed at the social contact. The divisions are ultimately required since one wants to communicate politely to the older men, and to become more friendly to the same age, and to be wiser to the younger age. The categories are (1) eleven old; (2) social context; and (3) friendship (Depdikbud, 1988, p. 171). Concerning this opinion, Hamidsyukrie (1994, p. 3) expresses that there are at least nine terms of addressing that commonly used by applied linguists. Still $\mathrm{n}$ the same paper, Hamidsyukrie et al. stressed that 4 of them are: pronoun, personal names, relative calls, and degree/title.

In Bima Regency, the Belo dialect is one of the dialects which exist in the Bima language. This region located in Sumbawa island. The regency is closer to Dompu regency through the land but closer to Ende through the sea. Geographically, Bima regency consists of two regions; East Bima and West Sanggar. The capital of Bima regency is Bima. (Bima District in Figure, 
2000). The difference between dialect and language lies in the mutually intelligible among the language community. Finally, the way of greeting one's name mostly similar, that is, by rewarding or honoring "lia" to the older or the charismatic figure. Bima people use Bima language as their mother tongue and for communication and interaction in their daily life in any activity of their life. Like any other subdistrict in Bima regency. The Bimanese in the Belo subdistrict, use terms of greeting names differently for different level, degree, or age.

The terms of greeting in any other region, the Bimanese language users also have specific rules or principles. Those rules are crucial since the communicator(s) are afraid to produce rude or even uncivilized man. Therefore, the communicator has to be able to employ the proper term of addresses to the correct men (interlocutor). Concerning the pattern of greeting name based on one's age, Hanafi (2001) states that Bima language uses interesting patterns in greetings related to the personal names. These features distinguished because of two things: (1) the greeter is younger than the one called (at least the difference in age is 2 (two) years) and (2) gender is called (male or female).

Furthermore, Hanafi (2001) also views that: "Bahasa Bima (BB) merupakan bahasa yang unik dalam sentuhannya dengan sapa diri. Selain karena konsonan yang lesap pada akhir pelafalan kata atau pemenggalan berdasarkan silabel. " It also equivalents to English that Bima language is a unique language in contact with. For instance, the disappearing of end consonant(s) in its utterance. To a similar case, the adult names can be exchanged (in the Belo dialect of the Bima language + lia). These facts are different from any other local language in Indonesia. For example (1) Sudirman, his syllable: /Sudi//Dirma //Ma) by older caller. (2) Syllable: /Sudi/ to become/Sedo//Dirma/ to become /Moa//Ma/ to become /Moa/

The pronunciation of personal names should be in the first syllable (s), middle syllable (s), or the end syllable(s). But, it is impossible to pronounce the end syllable, which indicates two forms of greeting personal names (Hanafi, 2001). Regarding politeness Brown and Levinson (1987, p. 67) state politeness in language indeed imperative to greet or address someone in social life to avoid conflicts that might occur within every communication interaction. However, politeness in speech is applied differently in each culture because every text cannot be separated from the context. In line with Brown and Levinson, Ellen (in Chaer 
and Leonie Agustina, 2010, p. 21) state that politeness is one of the principles in language use. In other words, it is crucial to consider the other person's feelings when communicating with others. Through considering the other peoples' sense, it will enable communication or interactions and social progress without threatening the face of the speakers or speech partners.

\section{RESEARCH METHOD}

The method used in recent research is a qualitative descriptive. An investigation with the qualitative approach is the research relied on verbal and non-numerical data as the basis of analysis and solving the problem appears (Farkhan, 2007, p. 6). Qualitative data obtained by asking questions indirectly or directly to the informants so that they provide information that does not restrict the participants' opinions (Creswell and Clark, 2011). Before undertaking the data, the informants were chosen based on fulfilling the criteria. There were at least four significant points of consideration of informants of the study, such as stated by Hamidsyukrie et al. (1994, p. 5), they are: (1) the native speakers; (2); actively used the language investigated (3) mentally and physically healthy; (4) up to 16 years old; and (5) to get ready to give information needed.

The procedures of collecting data used interviews, recording while the researcher conversation with the informants, documentation, note-taking, and relevant sources that support the information needed. The researcher interviewed and communication with the informants directly in Belo dialect used tape-recorder then transcribed carefully and concisely (Mahsun, 2012, pp. 95-96). The researcher also applied note-taking techniques.

The primary data of this recent research obtained directly from the informants in the research sample areas, which were well representative Belo dialect in the Bima language. The real procedures of analyzing the data followed Miles and Hubermann (1984), which includes data presentation, data reduction, and drawing conclusions and verification of findings. Furthermore, to guarantee the accuracy and limitations of the data, the triangulation technique applied to ensure the research methods, data collection, and data analysis techniques valid and reliable. 


\section{RESULT AND DISCUSSION}

The recent article expects to reveal the greeting system practice in the Bima language, especially in Belo dialect (BD). After conducting a long journey of investigation, reciprocating to the native speakers of the Bima language, the researcher, then found out the uniqueness of Bima's people or Bimanese in greeting system of personal names mainly used by the Belo people. During the investigation, he found himself really "melted together" to the natives. So, he got the original facts of the matters discussed. There are two main variations of greeting or addressing names usually used in the Belo dialect. The variations of greeting/calling names are different from male and female, which applied in daily interactions of Bima language. Under detail explanations, the investigation divided into several components. There are four patterns of variation in greeting male's names in Belo dialect of Bima language. The first pattern is constructed from the syllable /e- $\mathrm{o} /$. This pattern of variation is the most number in Bima language variation in daily greeting personal names use. The greeting of personal names shows the difference based on who is the caller of the names. The sample of greeting names can be seen in Table 1 below.

Table 1. Variation of Daily Greeting Personal Male Names in Syllable /e-o/

\begin{tabular}{lll}
\hline \multicolumn{2}{c}{ Greeting Variation } & \multirow{2}{*}{ Proper Name } \\
\cline { 1 - 2 } Counger & Older/same & \\
\hline Bedo & age Caller & \\
Beho & Bidi & Abidin \\
Beko & Baha & Baharudin \\
Bero & Burha, Buru & Bbubakar \\
Deo & Nurdi & Nurdin \\
Delo & Dula, Dola & Abdullah \\
Dero & Dara & Darham \\
Heko & Haka & Ishaka \\
Helo & Hali & Halik
\end{tabular}




\begin{tabular}{lll} 
Hemo & Hami & Hamid \\
Hima & & \\
Melo & Mali & Amlik \\
Semo & Sama & Samad \\
Kero & Kari & Karim \\
Mejo & Maji & Majid \\
Keso & Kasi & Kasim \\
Deo & Haidi & Haidir \\
Jeo & Hanja & Hamjah \\
Kedo & Kadi & Kadir \\
Medo & Sumadi & Sumadin \\
Seno & Suna, Sunardi & Sunardin \\
\hline
\end{tabular}

Table 1 depicts patterns or variations of greeting personal male names in Belo dialect of Bima language. To call/greet one's name in Belo dialect, the people use several rules, such as follows: the first variation of greeting names of the younger caller to the older called. The way of greeting the older's name meant to consider the politeness, such as Bedo for the proper name Abidin, Beho for the proper name Baharuddin, and Beko for the proper name Abubakar. The second variation of greeting names of the older caller to the younger called, such as in Bidi for the proper name Abidin, Baka for the proper name Abubakar, and Nurdi for the proper name Nurdin. The third, the variation of calling names of the same age/the same level callers. To this extent, the younger callers, for instance, appreciate much the honor of the adults. Such polite expressions also determine deep respect. Next, the most patterns greeting male names of older and same-age callers to youngers tend to be greeted or called by omitting the last letter of the proper name.

In regard the finding above, Brewer (1981) states that based on his research under the title "Bimanese Personal Names: The View from Bima Town and Donggo" Bimanese people has a unique pattern in addressing personal names, even though among one to another subdistrict has slightly difference each other. The result above can be viewed from the cultural perspective, Brown and Levinson (in Gunarwan, 1994, p. 6) explain that the speaker chooses the strategy by considering the levels threat of "face" based on the social distance of both the 
speaker and the speaker. The difference in social status and power between speaker one and speaker two make the strategies or patterns in their communication difference to each other. The other aspect usually considered by the speakers in communication is a cultural aspect or concern. In other words, the cultural perspective becomes a crucial thing to be cared about in maintaining conversation continuity. In line with Brown and Levinson, Nwoye (1992) stresses that politeness is an essential aspect of verbal communication and involved the strategies for maintaining social interaction among the speakers. Furthermore, Nwoy states that the actual using of the strategies in certain social settings may differ from the other tradition or cultural context. The next variation of daily greeting personal male names constructed by syllable /ia/ as in Table 2 .

Table 2. Variation of Daily Greeting Personal Names in Syllable /i-a/

\begin{tabular}{cll}
\hline \multicolumn{2}{c}{ Greeting Variation } & Proper Name \\
Younger & Older/same & \\
Caller & age Caller & \\
\cline { 1 - 2 } Hima & Hama, & Ahmad \\
Hima & Muhama & Muhammad \\
\hline
\end{tabular}

Table 3. Variation of Daily Greeting Personal Names in Syllable /o-e/

\begin{tabular}{lll}
\hline \multicolumn{2}{c}{ Greeting Variation } & Proper Name \\
Younger & Older/same & \\
Caller & age Caller & \\
\hline Delo, & Dola, Dula & Abdullah \\
Dole & Abdula & \\
& & \\
\hline
\end{tabular}


Table 4. Variation of Daily Greeting Personal Names in Syllable /i-e/

\begin{tabular}{lll}
\hline \multicolumn{2}{c}{ Greeting Variation } & Proper Name \\
$\begin{array}{c}\text { Younger } \\
\text { Caller }\end{array}$ & Older/same & \\
age Caller & \\
Sile & Sala, & Salahudin, \\
Sile & Mursali, Sali, & Mursalim \\
Sile & Sali & Salim \\
Sile & Sale & Saleh
\end{tabular}

Based on results as depicted in Tables 2, 3, and 4 above, the results tell us about the greeting variations of personal male names in Belo dialect based on syllables of vowel pairs. From the three tables, it is apparent that Table 4 is a more productive variation of greeting personal male names than Table 2 and Table 3. Table 4 shows a similar pattern or way of greeting/addressing to some different names when greeted by the younger callers. Otherwise, the greeting is variation when are greeted by the older or same age callers.

Tables 2 shows the less productive in greeting personal names in Belo dialect (BD). The greeting constructed from the syllables / $\mathrm{i}-\mathrm{a} /$, as in proper names Ahmad and Muhammad. Both names are greeted with Hima when they greeted by younger callers. Furthermore, the greeting is different when the names are greeted or addressed by the older or same-age callers.

Next, Table 3 depicts further finding regarding the pattern of constructing the greeting of personal name in the Belo dialect. The personal greeting names use syllable /o-e/ for the younger caller for Delo and Dole for the proper name Abdullah. As happened in the personal greeting as seen in Table 2 above, the variation of greeting personal names is more productive when it is called or greeted by the older or same-age callers than younger ones. 
Regarding these findings are in line with (Erwin Wayan \& Arifin, 2013) under their research title Penggunaan Bahasa Mbojo Di Lingkungan Masyarakat Bima Di Bima: Sebuah Kajian Variasi Bahasa state that personal greeting names in Belo dialect of Bima language. Bimanese or Bima people have some variations based on their age, sex, and position. Furthermore, they express that there are two levels of politeness variations, namely moderate and less politeness

The further result is the variation of greeting female names in Belo dialect presented from Tables 5 up to Table 12 respectively.

Table 5. Variation of Daily Greeting Personal Female Names in Syllable /a-u/

\begin{tabular}{|c|c|c|}
\hline Greet & ng Variation & Proper \\
\hline $\begin{array}{l}\text { Younger } \\
\text { Caller }\end{array}$ & $\begin{array}{l}\text { Older } \\
\text { Caller/Same } \\
\text { Age }\end{array}$ & Name \\
\hline $\mathrm{Bau}$ & Bia, Arabia, & Arabiah \\
\hline Bau & Misba & Misbah \\
\hline Lau & Ramla, Laila & $\begin{array}{l}\text { Ramlah, } \\
\text { Lailah }\end{array}$ \\
\hline $\mathrm{Jau}$ & Jahara & $\begin{array}{l}\text { Jaharah, } \\
\text { Jahora }\end{array}$ \\
\hline Mau & Muala & Maulanah \\
\hline Tau & Mariati, Ati, Ti & Maryati \\
\hline Fau & Darfia, Sarfia & $\begin{array}{l}\text { Darfiah, } \\
\text { Sarfiah }\end{array}$ \\
\hline
\end{tabular}




$\begin{array}{lll}\text { Hawu } & \text { Hawa } & \text { Siti Hawah } \\ \text { Janu } & \text { Jana, Nurjana } & \text { Nurjanah } \\ \text { Nau } & \text { Ratna, Misna, } & \text { Ratnah, } \\ & \text { Nuraeni } & \text { Misnah, } \\ & & \text { Nuraeni }\end{array}$

Table 5 shows the variety of greeting personal names for females in Belo dialect (BD) of Bima language (BL). From ten female names show the difference of greeting between the younger callers and older or same-age callers. The younger callers to the older people have less choice or variation than older and same-age callers. The younger callers have a unique greeting to older people, as in Arabiah, Ramlah, Laila, Jahara, Maulana, and Mariati. But for greeting names Fau for Darfiah, Sarfiah, Jau for Jahara and Jahora; Lau for Ramlah and Lailah; Nau for Ratna, Misnah, Nur'aini; and Wau for Ma'awiah and Marwiah.

Meanwhile the variety of greeting personal name which addressed/greeted by older and same-age callers has more variations than younger callers. Based on result in Table 5 above, it shows at least two ways of greeting personal female names both older callers and same-age ones.

Table 6. Variation of Daily Greeting Female Names in Syllable /e—o/

\begin{tabular}{lll}
\hline \multicolumn{2}{c}{ Greeting Variation } & Proper \\
Younger & Older & Name \\
Caller & Caller/Same & \\
& Age & \\
& Ani, Ma'ani & Ma'ani \\
Eno & Gaya, Rugaya & Rugayah \\
Eo & Ma'ia, Ma, Ia & Ma'iah \\
Eto & Ma'atu, Atu & Ma'atu
\end{tabular}




\begin{tabular}{|c|c|c|}
\hline $\begin{array}{l}\text { Heno, } \\
\text { Nefo }\end{array}$ & Hani, Hanifa & Hanifah \\
\hline Jeo & Jauhari, Jau & Jauhari \\
\hline \multirow[t]{2}{*}{ Mero } & Mariati, & Mariati \\
\hline & Asmara & Asmara \\
\hline Feo & Fia, Safia & $\begin{array}{l}\text { Safiah, } \\
\text { Sarfiah }\end{array}$ \\
\hline Sero & Sara, Sarfia & Sarafiah \\
\hline
\end{tabular}

Table 6 above shows the different ways of greeting personal names for females in Belo dialect (BD) of Bima language (BL). From eleven (11) proper names found the difference of greeting between the younger callers and older and same-age callers. The younger caller to the older people has only one choice to greet or call older female names. But in greeting personal names by the older and same-age callers has at least two ways or choices each name. There is a proper name $M a$ 'iah is called or greeted with three ways Ma'ia, Ma, and Ia. Besides, the proper name Hanifah can be greeted by the younger callers in two ways, namely Heno and Nefo. Meanwhile, the proper names Mariati and Asmara may be addressed or called by younger callers with one greeting, namely Mero.

Table 7. Variation of Daily Greeting Female Names in Syllable /o-a/

\begin{tabular}{lll}
\hline \multicolumn{2}{c}{ Greeting Variation } & Proper \\
Younger & Older & Name \\
Caller & Caller/Same \\
& Age \\
& \\
\hline
\end{tabular}




\begin{tabular}{lll}
\hline Moa & Salma, Ma, & Salmah, \\
Mae, Sarmae & Sarmae, \\
& Fatma, Ma & Fatmah
\end{tabular}

The finding, as seen in Table 7 shows the different ways of personal greeting names for females in Belo dialect (BD) of Bima language (BL). From three (3) proper names (Salmah, Sarmae, and Fatmah) which follow the pattern of construction /o- $\mathrm{a} /$ in greeting personal female names by the younger callers. The three proper names called with one greeting name, namely Moa. Meanwhile, the variation of greeting name by older and same-age callers are two ways, they are Salma and Ma for Salmah; Sarmae and Mae for Sarmae; and Fatma and Ma for Fatmah.

Table 8. Variation of Daily Greeting Female Names in Syllable /a-o/

\begin{tabular}{lll}
\hline \multicolumn{2}{c}{ Greeting Variation } & Proper \\
Younger & Older & Name \\
& Caller/Same & \\
& Age & \\
\hline Rao & Maria, Ria, & Maria, \\
& Mariama, Maria & Mariamah, \\
& Mariana, Maria & Marianah \\
& Juria, Ria, & Juriah \\
& Juhria, Ria & Juhriah \\
& Jumra & Jumrah
\end{tabular}

Table 8 presents the results from the data analysis which used the pattern of greeting female names. This finding shows the difference from the other designs as in the previous tables. The finding in Table 5 above may be called a unique construction, especially in greeting female names for younger callers to older people, especially for female names. There are six (6) names may be called with one greeting or addressing, such as Maria, Mariamah, Marianah, Juriah, 
Juhriah, and Jumrah. Otherwise the greeting of female names is called by the older and sameage callers are more variations. Each of the proper names has two variations, but only one name has no variation or other option, namely Jumra for Jumrah.

Table 9. Variation of Daily Greeting Female Names in Syllable /e-i/

\begin{tabular}{lll}
\hline \multicolumn{2}{c}{ Greeting Variation } & Proper \\
\cline { 1 - 1 } Younger & Older & Name \\
Caller & Caller/Same & \\
& Age & \\
& & Jaenab \\
Jei & Jaena, Junari & Samsiah, \\
Sei & Samsia & Kalisom \\
& Kaliso &
\end{tabular}

Sei, Moa Sarmae, Mae Sarmaeh

Table 9 provides the result regarding the patterns of greeting female names using syllable /e$\mathrm{i} /$. there are four proper names. There is a female name has two ways for younger caller to older people, such as Sei and Moa for Sarmaeh. Thre are two names that have one way of greeting the female names, as in younger callers, Sei for Samsiah and Kalisom. Meanwhile the older and same-age callers have only one way or choice to greet or call both Samsiah and Kalisom. The last greeting variation in this pattern is the older and same-age callers have two ways or choices to greet or address the proper name Sarmaeh.

Table 10. Variation of Daily Greeting Female Names in Syllable /o-i/

\begin{tabular}{|c|c|c|}
\hline \multicolumn{2}{|c|}{ Greeting Variation } & Proper \\
\hline Younger & Older & Name \\
\hline Caller & & \\
\hline
\end{tabular}




\section{Caller/Same}

Age

\begin{tabular}{lll}
\hline Bodi & Jubaida, Beda & Jubaidah \\
Doji & Dija, Hadija & Hadijah \\
Losi & Lisa, Halisa & Halisah \\
Rofi & Sarifa, Rifa & Sarifah \\
Lomi & Halima, Lima & Halimah
\end{tabular}

As can be seen from Table 10 above, the pattern of greeting female names for younger callers to older people using syllable /o-i/. From five female names found that each name has only one way or choice to greet or call when it is called or greeted by younger callers, such Bodi for Jubaidah; Doji for Hadijah; Losi for Halisah. Rofi for Sarifah, and Lomi for Halimah. However, each of five names as presented in Table 5 above has two ways or choices when they are greeted or called by older and same-age callers.

Table 11. Variation of Daily Greeting Personal Names in Syllable /e-e/

\begin{tabular}{lll}
\hline \multicolumn{2}{c}{ Greeting Variation } & Proper \\
\cline { 1 - 2 } Younger & Older & Name \\
Caller & Caller/Same & \\
& Age & Maemunah \\
\hline Mene & Muna, & \\
& Maemuna & \\
& Mini, & Rukmini \\
& Rukmini &
\end{tabular}

Table 11 shows the variation of greeting female names using syllable pattern /e-e/ for younger caller to older people. There is only one choice of greeting two female names, namely 
Maemunah and Rukmini. Both names greeted or addressed with Mene. Meanwhile the older and same-age callers have two ways or choices to greet and call them, such as Muna and Maemuna for Maemunah; and Mini and Rukmini for Rukmini. But there is one proper name, namely Rumini has the same greeting, both older callers and same-age callers. It means that there is no omitting final phoneme ' $h$ ' in this name. In other words, this name is unique to other Bimanese female names. Regarding this finding, Hanafi (2001) stresses that: "Bahasa Bima (BB) merupakan bahasa yang unik dalam sentuhannya dengan sapa diri. Selain karena konsonan yang lesap pada akhir pelafalan kata atau pemenggalan berdasarkan silabel.”

Translation: Bima is a unique language along with its its personal address. Instead of the ellipsis of consontant on the last part of the pronunciation or the syllable division"

Table 12. Variation of Daily Greeting Female Names in Syllable /o- $\mathrm{o} /$

\begin{tabular}{lll}
\hline \multicolumn{2}{c}{ Greeting Variation } & Proper \\
Younger & Older & Name \\
Caller & Caller/Same & \\
& Age & \\
& Habiba, Biba & Habibah \\
\hline Bobo & & \\
\hline
\end{tabular}

It can be seen from the data in Table 12 that there is only one name found using this pattern construction in greeting female names of Bima people. The variation of greeting occurs only in older and same-age callers, such as Habiba and Biba for Habibah. Meanwhile, as the most common of greeting female names, especially the callers or greeters are younger than the people are called or greeted.

Based on the results as shown in eight tables (Table 5 up to Table 12) above, they can be classified into three levels of variations, namely high variation, as in Tables 5 and Table 6; moderate level variation as seen in Tables 7, 8, and 9, 10; and low variety as in Table 11 and Table 12). The other exciting aspect of greeting female names is the most variation of greeting 
names that occur on older callers and same-age callers, as shown in all tables (Tables 5-12). In contrast, the variation of greeting personal names of younger callers tends to low productivity, but they still have politeness value.

Regarding the result of this study, Anchimbe (2011) based on his research results under his research title "On not calling people by their names: Pragmatic undertones of socio-cultural relationships in a post-colony found that to greeting people by their proper names in certain cultures is not only disrespectful but also an indication that they have no respect or have no politeness. In line with this opinion, Manno (2005) strengthens that politeness comprises not only reducing the face-strengthening act (negative politeness) but also creating polite acts, for example, compliment, greeting, etcetera (positive politeness). The other research result comes from Schneider (2017) with his research title "( $\mathrm{Im})$ politeness and regional variation" supports the tworesearch result before, that in macro-social interaction, gender and age factors may affect the language use, not only at the national, sub-national, and local level.

Furthermore, to answer the second question posed before, which related to how are the use of variations pattern in the greeting of personal names in Belo dialect of Bima language? Regarding the answer to this question, it can be revealed based on the above results. The ways of using variations in greeting personal names in the Belo dialect of Bima language consists of three ways. The three variation patterns of greeting personal names, namely at the beginning, such as in proper names Kasim to become Keso and Hamid to become Hemo or Hima; the middle, such as in proper name Abidin to become Bedo, and Aldi to become Deo; and at the end of the syllables, such as in proper name Ramli to become Leo and Hamdin to become Deo. These examples as seen above are the most often used and natural occurrence when Bimanese people interact in daily life. Related to this finding Ahn, H. (2017) stated in his research finding that terms of greeting used by callers communication happen the callers/speakers always consider the appropriately linguistic features and specific cultural embraced by the addressee (younger, older, or same age) as a means of precisely designating individuals.

Regarding the results above, Belo dialect of the Bima language has unique variation patterns and systems of greeting both male's and female's names. In line with this finding, Montemurro at al. (2016), in any language, there are many signals produced by complex systems, such as phoneme sounds and words, and its meaning within. Besides that Malt, at al. (2003) expressed another aspect of language use, it based on their research result stated that in 
using language, the speakers need to know not only the individual elements, such as his/her cultural aspect which they are embraced but also of the language they speak. Regarding this concern. Alek (2018, p. 9) says more explicitly in his book 'Linguistik Umum' that language is a variety. It means that each language or dialect used by a group of the language community that owned by a language society. The diversity of communication has an impact on the patterns of the formation of specific systems that are adopted by a language, such as in the variation of syllable of vowel patterns in greeting system of people's names in the Belo dialect. Similar to Alek, Sri (2016) stated that language is a unique sound pattern according to the way of the channel and according to its acoustic properties (phonetic articulatory). Speech is the process of producing air through the mouth and the role of all utensils. Furthermore, Sri stressed that all utterances or sentences produced should have meaning and meaningful.

\section{CONCLUSION}

The present investigation definitely answers the questions regarding greeting practice of personal names in the Bima language, especially in Belo dialect. The results indicated that there are differences between males and females in the greeting of personal names. There are four variations or patterns in male's greeting their personal names. In the meantime, there are nine patterns of syllable of vowel variations in constructing the greeting of female's names in Belo dialect of Bima language. The other result related the process of building the patterns or variations in greeting both male and female names consist of three variation patterns, namely at the beginning (Kasim for Keso), in the middle (Nurdin for Deo), and the last is at the end of the syllables (Bakri for Reo). The variation found in this study not only the patterns of syllables or vowel pairs but also the name variation in the way of greeting some personal names, both in male's name and female's name when they are called by older or same age speakers/callers. The other important result indicates that the most syllable /e- $\mathrm{O} /$ for male and syllable / $\mathrm{a}-\mathrm{u} /$ and $/ \mathrm{e}-\mathrm{O}$ / for female names. The other important uniqueness found in this study is that of all final letters or phonemes in greeting personal names, both males and females in the Bima language ending with 'vowel letter.' In societal life, personal greeting names may differ from a language community to another language community; it is strongly affected by the culture embraced and the level of closeness among the speakers. 
The finding of the recent study suggests that the language teachers, the language planners of Bima language, includes Belo dialect to scrutinize the aspects that have not revealed yet within the investigation. Last but not least, the local language not only a means of communication among the speaker of the language but also to support the development of the national language.

\section{REFERENCES}

Alek. (2018). Linguistik Umum. Jakarta: PT Erlangga.

Alek. (2005). "Verba Transitive Bahasa: Sebuah Kajian Morfosintaktis,”Tesis, Universitas Negeri Jakarta.

Ahn, H. (2017). Seoul uncle: Cultural conceptualizations behind the use of address terms in Korean. In Advances in Cultural Linguistics (pp. 411-431). Springer, Singapore. Retrieved on October 7, 2019, form https://link.springer.com/chapter/10.1007/978981-10-4056-6_19. Time Accessed 23:10.

Anchimbe, E. A. (2011). On not calling people by their names: Pragmatic undertones of socio-cultural relationships in a post-colony. Journal of Pragmatics, 43(6), 1472-1483. Retrieved from https://www.sciencedirect.com/science/article/abs/pii/S0378216610003310

Ayatrohaedi. (2002). Pedoman Praktis: Penelitian Dialektologi. Jakarta: Pusat Pembinaan dan Pengembangan Bahasa Depdikbud.

BPS, 2000. Bima District in Figure.

Brewer, J. D. (1981). Bimanese personal names: Meaning and use. Ethnology, 20(3), 203-215. Derived on September 7, 2019.

https://scholar.google.com/scholar?hl=id\&as_sdt=0\%2C5\&q=addressing+names+in+ Bima+language \&btnG=\#d=gs_cit\&u=\%2Fscholar\%3Fq\%3Dinfo\%3A0yCFFD9umQ0 J\%3Ascholar.google.com\%2F\%26output\%3Dcite\%26scirp\%3D0\%26hl\%3Did

Cahyono, Bambang Yudi. (1995). Kristal-Kristal Ilmu Bahasa. Surabaya: Airlangga University Press.

Chaer, Abdul. (1994). Linguistik Umum. Jakarta: Rineka Cipta.

Chaidir Alwasilah, A. (1990). Linguistik Suatu Pengantar, Bandung: PT Angkasa. 
Croft, W. (2017). Evolutionary complexity of social cognition, semasiographic sys, and language. S., Mufwene, C., Coupé, F. Pellegrino,(Eds.), Complexity in language, 101134. Derived on October 8, 2019, Time accessed 22:58 from https://books.google.co.id/books?hl=id\&lr=\&id=b1pEDgAAQBAJ\&oi=fnd\&pg=PA1 $\underline{01 \& \mathrm{dq}=\text { greeting+or+addressing+system+of+personal+names+in+the+local+language }}$ $\underline{\text { ots }}=5 \mathrm{GDjL}-$

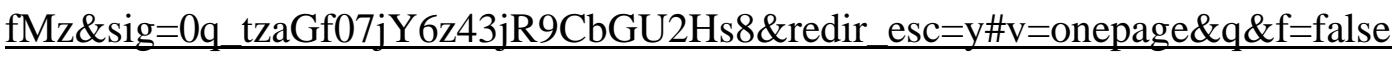
Depdikbud. (1998). Tata Bahasa Baku Bahasa Indonesia, Jakarta: Balai Pustaka.

Dinner, Francais. (1958). An Introduction to Descriptive Linguistics, New York: Winston.

Erwin Wayan, R., \& Arifin. (2013). Penggunaan Bahasa Mbojo Di Lingkungan Masyarakat Bima Di Bima: Sebuah Kajian Variasi Bahasa. E-Journal Program Pascasarjana Universitas Pendidikan Ganesha, 2.

Felecan, D. (2015). Conventional vs unconventional linguistic means of address. (Old and new greetings in Romanian). Diacronia, (1), 1-23. Retrieved on October 7, 2019, from https://www.ceeol.com/search/article-detail $\mathrm{id}=541091$

Gunarwan, Asim. (1994). Kesantunan Negatif di Kalangan Dwibahasawan Indonesia-Jawa di Jakarta: Kajian Sosioprgmatik (PELLBA 7). Jakarta: Lembaga Bahasa Unika Atma Jaya

Hadi, Sutrisno. (1994). Pengantar Penelitian Ilmiah, Bandung: PT Tarsito.

Hanafi, Nurrahman. (2001). Perilaku Diftong pada Sapa Diri Berbahasa Bima, UNRAM Laporan Penelitian.

Hamidsyukrie, Z.M., Ali, Nasaruddin M, Arifudin. (1994). Sistem Sapaan dalam Bahasa Bima, Mataram: Laporan Penelitian FKIP-Unram.

Holmes, J. (1992). An Introduction to Sosiolinguistics. London: Langman.

Kridalaksana, Harimurti. (1984). Kamus Linguistik, Ed. II, Jakarta: PT Gramedia.

Kurniawati, Sri. (1998). Morphological Process of Bahasa Bima, Ujung Pandang: A thesis.

Malt, B. C., Sloman, S. A., \& Gennari, S. P. (2003). Universality and language specificity in object naming. Journal of memory and language, 49(1), 20-42. Retrieve October 8, 2019, Time accessed 08:22 p.m, from https://www.sciencedirect.com/science/article/pii/S0749596X03000214 
Manno, G. (2005). Politeness in Switzerland: Between respect and acceptance. Politeness in Europe, 127, 100. Retrieved on September 7, 2019. Time: 20:37. https://books.google.co.id/books?hl=id\&lr=\&id=8h6abwB15Q0C\&oi=fnd\&pg=PA10 $\underline{0 \& \mathrm{dq}=\text { variation+of+greeting }+ \text { personal+names+of }+ \text { younger+callers+tends+to+low+pr }}$ oductivity,+but+they+still+have+politeness+value.\&ots=DV3V4I9cvQ\&sig=EnIwhY hu6D0DHRt5pIBd-wtXaMc\&redir_esc=y\#v=onepage\&q\&f=false

Montemurro, M. A., \& Zanette, D. H.. (2016). Complexity and universality in the long-range order of words. In Creativity and Universality in Language (pp. 27-41). Springer, Cham. Retrieved on October 8, 20the 19, time accessed 08:45.a.m. from https://link.springer.com/chapter/10.1007/978-3-319-24403-7_3

https://en.wikipedia.org/wiki/Main_Page Bima at Ethnologue (18th ed., 2015)

Hammarström, Harald; Forkel, Robert; Haspelmath, Martin; Bank, Sebastian, eds. 2016.

"Bima". Glottolog 2.7. Jena: Max Planck Institute for the Science of Human History. http://pasca.undiksha.ac.id/e-journal/index.php/jurnal_bahasa/article/view/873

Ismail, Mansur et al. (1985). Kamus Bima-Indonesia. Jakarta: Pusat Pembinaan dan Pengembangan Bahasa Depdikbud.

Jendra, I Wayan. (2007). Sosiolinguistik: Teori dan Penerapannya. Surabaya: Paramita. Loir, Hendri Chambert \& Maryam. (1999). Bo’ Sangaji Kai (Catatan Kerajaan Bima). Jakarta: Yayasan Obor Indonesia.

Mahsun. (1995). Dialektologi Diakronis. Yogyakarta: Gadjah Mada University Press. Mahsun. (2005). Metode Penelitian Bahasa. Jakarta: Raja Grafindo Persada.

Nababan, P.W.J. (1991). Sosiolinguistik Suatu Pengantar. Jakarta: Gramedia Pustaka Utama. Nwoye, O. G. (1992). Linguistic politeness and socio-cultural variations of the notion of face. Journal of pragmatics, 18(4), 309-328. Derived on October 7, 2019, from https://www.sciencedirect.com/science/article/abs/pii/037821669290092P\#!

Pennesi, K. E. (2017). Universal Design for Belonging: Living and Working with Diverse Personal Names. Journal of Belonging, Identity, Language and Diversity ( $J$ BILD), 1(1), 25. Retrieved on October 10, 2019, from https://ir.lib.uwo.ca/anthropub/64/

Risager, K. (2005). Languaculture as a key concept in language and culture teaching. The consequences of mobility, 185-Retrieved on October 10, 2019, on https://rucforsk.ruc.dk/ws/files/37440173/Risager.pdf. 
Schneider, K. P., \& Placencia, M. E. (2017). (Im) politeness and regional variation. In The Palgrave Handbook of Linguistic (Im) politeness (pp. 539-570). Palgrave Macmillan, London. Retrieved on October 7, 2019, Time: 20:44 from https://link.springer.com/chapter/10.1057/978-1-137-37508-7_21

Sugiyono. (2010). Metode Penelitian Kualitatif, Kuantitatif, dan R \& D. Bandung: Alfabeta. Suhardi, Basuki. (2009). Pedoman Penelitian Sosiolinguistik. Jakarta Timur: Pusat Bahasa Departemen Pendidikan Nasional.

Tajib. Abdullah. (1995). Sejarah Bima Dana Mbojo. Raba-Bima: PT Harapan.

Yannuar, N., Iragiliati, E., \& Zen, E. L. (2017). Bòsò Walikan Malang's Address

Practices. GEMA Online ${ }^{\circledR}$ Journal of Language Studies, 17(1). Pp. 107-123.

Retieved on October 10, 2019 from http://ejournal.ukm.my/gema/article/view/11632. Time accessed 22:22

Yunus, Anwar. (1985). Kamus Bahasa Bima - Indonesia (Nggahi Mbojo), Yayasan Muhammad Salahuddin Jakarta.

Wardaugh, Ronald. (1998). An introduction to Sociolinguistics. Oxford: Basil Blackwell Ltd.

Widiasri, D. A. (2016). Penyimpangan Pola Fonologis Bahasa Inggris Siswa SD Tampak Siring. Menara Ilmu, 10 (72). Vol. X Jilid 1 No.72 November 2016 MENARA Il. Retrieved from http:// https://scholar.google.co.id/scholar?hl=en\&as_sdt=0\%2C5\&q=variasi+pola+silabel+k $\underline{\text { ata\&btnG}=1}$ 